\title{
Hydrophobic analogues of rhodamine $B$ and rhodamine 101: potent fluorescent probes of mitochondria in living $C$. elegans
}

\author{
Laurie F. Mottram ${ }^{1}$, Safiyyah Forbes ${ }^{1}$, Brian D. Ackley ${ }^{2}$ \\ and Blake R. Peterson ${ }^{* 1}$
}

\section{Full Research Paper}

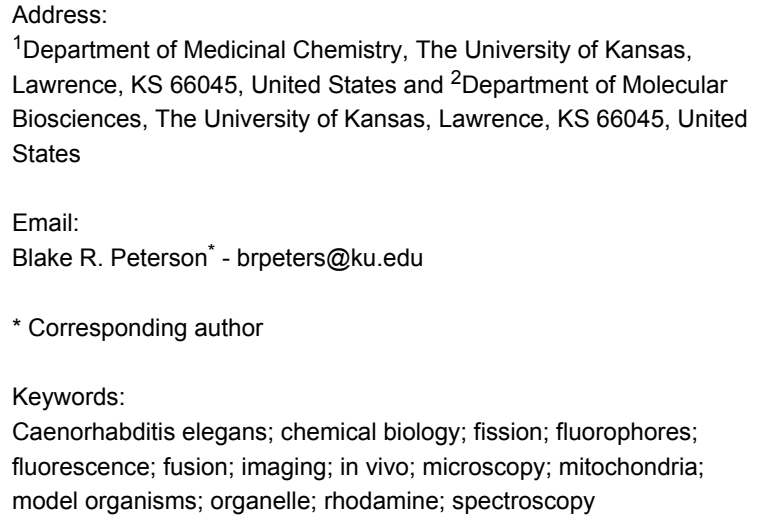

${ }^{1}$ Department of Medicinal Chemistry, The University of Kansas, Lawrence, KS 66045, United States and ${ }^{2}$ Department of Molecular Biosciences, The University of Kansas, Lawrence, KS 66045, United States

Email:

Blake R. Peterson* - brpeters@ku.edu

* Corresponding author

Keywords:

Caenorhabditis elegans; chemical biology; fission; fluorophores; fluorescence; fusion; imaging; in vivo; microscopy; mitochondria; model organisms; organelle; rhodamine; spectroscopy

Beilstein J. Org. Chem. 2012, 8, 2156-2165. doi:10.3762/bjoc.8.243

Received: 29 September 2012

Accepted: 09 November 2012

Published: 11 December 2012

This article is part of the Thematic Series "Synthetic probes for the study of biological function".

Guest Editor: J. Aube

(c) 2012 Mottram et al; licensee Beilstein-Institut. License and terms: see end of document.

\begin{abstract}
Mitochondria undergo dynamic fusion and fission events that affect the structure and function of these critical energy-producing cellular organelles. Defects in these dynamic processes have been implicated in a wide range of human diseases including ischemia, neurodegeneration, metabolic disease, and cancer. To provide new tools for imaging of mitochondria in vivo, we synthesized novel hydrophobic analogues of the red fluorescent dyes rhodamine B and rhodamine 101 that replace the carboxylate with a methyl group. Compared to the parent compounds, methyl analogues termed HRB and HR101 exhibit slightly red-shifted absorbance and emission spectra (5-9 nm), modest reductions in molar extinction coefficent and quantum yield, and enhanced partitioning into octanol compared with aqueous buffer of 10-fold or more. Comparison of living C. elegans (nematode roundworm) animals treated with the classic fluorescent mitochondrial stains rhodamine 123 , rhodamine $6 \mathrm{G}$, and rhodamine $\mathrm{B}$, as well as the structurally related fluorophores rhodamine 101, and basic violet 11, revealed that HRB and HR101 are the most potent mitochondrial probes, enabling imaging of mitochondrial motility, fusion, and fission in the germline and other tissues by confocal laser scanning microscopy after treatment for $2 \mathrm{~h}$ at concentrations as low as 100 picomolar. Because transgenes are poorly expressed in the germline of these animals, these small molecules represent superior tools for labeling dynamic mitochondria in this tissue compared with the expression of mitochondria-targeted fluorescent proteins. The high bioavailabilty of these novel fluorescent probes may facilitate the identification of agents and factors that affect diverse aspects of mitochondrial biology in vivo.
\end{abstract}




\section{Introduction}

Fluorescent molecular probes represent critical tools for studies of chemical biology [1]. These compounds allow the creation of sensitive enzyme substrates, sensors of a wide variety of analytes, and specific markers of cellular organelles and other components. Although many structurally diverse fluorophores have been reported, many common fluorophores such as dianionic fluorescein (1, Figure 1) are defined by highly polar conjugated $\pi$ systems. This high polarity confers substantial aqueous solubility, which is beneficial for some applications, such as protein labeling, but also results in low cellular permeability in assays involving living cells. Hydrophobic analogues of fluorescein such as Tokyo Green (2) [2], Pennsylvania Green (3) $[3,4]$, and others [5] have been synthesized that replace a carboxylate with a methyl group or other less polar functionality. These hydrophobic analogues are generally more effective at penetrating cellular membranes $[2,4]$.

Rhodamines such as rhodamine $123(4)$, rhodamine B (5), basic violet $11(6)$, rhodamine $6 \mathrm{G}(7)$, and rhodamine $101(\mathbf{8})$ are renowned for their red-shifted fluorescence, photostability, and high quantum yields over a wide range of $\mathrm{pH}$ values (i.e., $\mathrm{pH}$ 4-10). These fluorophores penetrate cells more readily than analogous fluorescein derivatives, because the negative plasma membrane potential within the cytoplasm of cells (typically -30 to $-60 \mathrm{mV}$ ) represents less of a barrier to entry to cations and zwitterions, compared with anionic compounds. Moreover, the delocalized cationic $\pi$-system of rhodamines further promotes their accumulation in energy-producing mitochondria, due to the even stronger negative potential across mitochondrial inner membranes (typically -120 to $-180 \mathrm{mV}$, depending on cell type) [6-9]. This membrane potential is critical for ATP synthesis, and is generated by pumping of protons across the mitochondrial inner membrane by the respiratory chain. Many delocalized lipophilic cations preferentially accumulate in these organelles, and some rosamines, i.e., compounds that lack the carboxylate of rhodamines [10], have been shown to potently depolarize mitochondria. Elevated mitochondrial membrane potential is a hallmark of cancer cell lines [11,12], and depolarization of mitochondria by rhodamines and rosamines can confer selective anticancer activity both in vitro and in vivo in animal models [13].

Under nontoxic conditions, rhodamines and mitochondriatargeted fluorescent proteins have been extensively used for imaging and analysis of these organelles in cell culture, enabling studies of dynamic fusion and fission events that are critical for mitochondrial structure and function [8,14-17]. Agents and factors that affect fusion and fission of mitochondria are of substantial interest [18] because disregulation of these dynamic processes has been implicated in a wide range of human diseases, including ischemia, neurodegeneration, metabolic disease, and cancer $[19,20]$.

In vivo, the pharmacokinetics of some rhodamines have been evaluated [21-23], and some have been used for imaging of mitochondria in the optically transparent model organism $C$. elegans (nematode worm) [24,25]. However, rhodamine 123 (4) [25], rhodamine B (5) [26], rhodamine 6G (7) [24], rhodamine<smiles>O=C([O-])c1ccccc1-c1c2ccc(=O)cc-2oc2cc([O-])ccc12</smiles>

Fluorescein (1)<smiles>[X]c1cc2c(-c3ccccc3C)c3cc([X])c(=O)cc-3oc2cc1[O-]</smiles>

Tokyo Green $(X=\mathrm{H}, 2)$ Pennsylvania Green $(X=F, 3)$<smiles>CC(=O)c1ccccc1-c1c2ccc(=[NH2+])cc-2oc2cc(N)ccc12</smiles>

Rhodamine 123 (4)<smiles>[R]OC([R])c1ccccc1-c1c2ccc(=[NH+]CC)cc-2oc2cc(N(CC)CC)ccc12</smiles>

Rhodamine $\mathrm{B}(\mathrm{R}=-\mathbf{5})$ Basic Violet $11(\mathrm{R}=\mathrm{Et}, \mathbf{6})$<smiles>CCNc1cc2oc3cc(=[NH+]CC)c(C)cc-3c(-c3ccccc3C(=O)OCC)c2cc1C</smiles>

Rhodamine 6G (7)

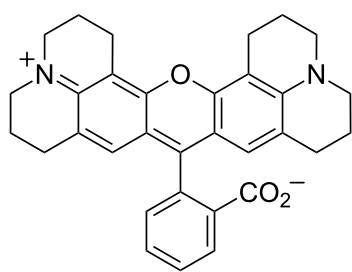

Rhodamine 101 (8)<smiles>CC[NH+]=c1ccc2c(-c3ccccc3C)c3ccc(N(CC)CC)cc3oc-2c1</smiles>

HRB (9)<smiles></smiles>

HR101 (10) 
B hexyl ester [27], and tetramethylrhodamine ethyl ester [27] are of low potency in living $C$. elegans, typically requiring treatment times of up to $48 \mathrm{~h}$ [24], often at concentrations as high as $30 \mu \mathrm{M}$ [27]. This low potency may have led some investigators interested in imaging fusion and fission of mitochondria in C. elegans [28] to forego the use of smallmolecule fluorescent probes and instead to use time-consuming molecular biology methods to generate transgenic animals that express fluorescent proteins, such as mitoGFP, that are targeted to this organelle. In general, the choice to use small-molecule probes or molecular-biology-based approaches for these types of imaging applications can be challenging because of our limited understanding of the bioavailability and bioaccumulation of small molecules in this model organism [29-34]. In general, these soil-dwelling nematodes are considered to be substantially less pemeant to small molecules than other animals, and most drug-like compounds do not efficiently accumulate in worms [30]. Consequently, to observe biological effects, many pharmacological agents must be added to $C$. elegans at concentrations orders of magnitude higher than are used with mammalian cells in culture $[35,36]$. For some hydrophobic compounds, delivery systems $[31,32]$ can improve their uptake.

We hypothesized that poor bioavailability of rhodamines in $C$. elegans may be responsible for their low potency as probes of mitochondria in this organism. We reasoned that the relatively high polarity of these charged compounds (e.g., LogD rhodamine $123(4)=0.53$ [37], -0.62 [9]), offering functional groups for possible xenobiotic metabolism in the intestine or other tissues [29,30], may limit absorption. Rhodamine esters such as 4, 6, and $\mathbf{7}$ may also be substrates of esterases [38] in vivo, resulting in the production of more polar fluorophores that may be inefficiently absorbed. To test this hypothesis, we synthesized novel hydrophobic analogues of rhodamine B (5) and rhodamine $101(\mathbf{8})$ that replace the carboxylate with a methyl group (Figure 1). The resulting analogues, termed HRB 9 and HR101 10, allowed evaluation of how subtle changes in chemical structure impact photophysical and physicochemical properties and the utility of rhodamines and analogues for imaging mitochondria in C. elegans. These studies revealed that the hydrophobic rosamines HRB 9 and HR101 10 represent highly potent and selective fluorescent probes of these organelles. Treatment of $C$. elegans with these compounds for as little as two hours at concentrations as low as $100 \mathrm{pM}$ enables selective imaging of mitochondria in vivo, including visualization of the dynamics of fusion and fission of these organelles in the germline of living animals.

\section{Results and Discussion Synthesis of fluorophores}

As shown in Scheme 1, the triarylmethane scaffolds of HRB 9 and HR101 10 were synthesized by condensation of the corresponding dialkyaminophenol with $o$-tolualdehyde (12) [39]. Oxidative cyclization of triarylmethanes with the quinone oxidant chloranil provided 9 and $\mathbf{1 0}$ in modest yield. 8-Hydroxyjulolidine (14) for synthesis of HR101 10 was either purchased commercially or prepared as previously described [40].

(A)<smiles>CCNc1cccc(O)c1</smiles>

11

(B)<smiles>Oc1ccc2c3c1CCCN3CCC2</smiles>

14<smiles>Cc1ccccc1C=O</smiles>

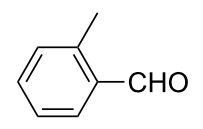

12

propionic acid $p$-TsOH, $85^{\circ} \mathrm{C}$ $p$ - $\mathrm{TsOH}, 85^{\circ} \mathrm{C}$<smiles>CCN(CC)c1ccc(C(c2ccccc2C)c2ccc(N(CC)CC)cc2O)c(O)c1</smiles>

$13(74 \%)$<smiles>Cc1ccccc1C(c1cc2c3c(c1)CCCN3CCC2)c1cc2c3c(c1O)CCCN3CCC2</smiles>

$15(84 \%)$<smiles>CCN(CC)c1ccc2c(-c3ccccc3C)c3ccc(=[N+](CC)CC)cc-3oc2c1</smiles>

$9(20 \%)$

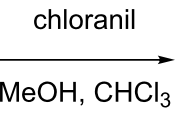<smiles></smiles>

$10(29 \%)$ 


\section{Photophysical and physicochemical prop- erties}

The absorbance (panel A) and fluorescence emission (panel B) spectra of fluorophores $\mathbf{4 , 5}$, and $\mathbf{8 - 1 0}$ are shown in Figure 2.
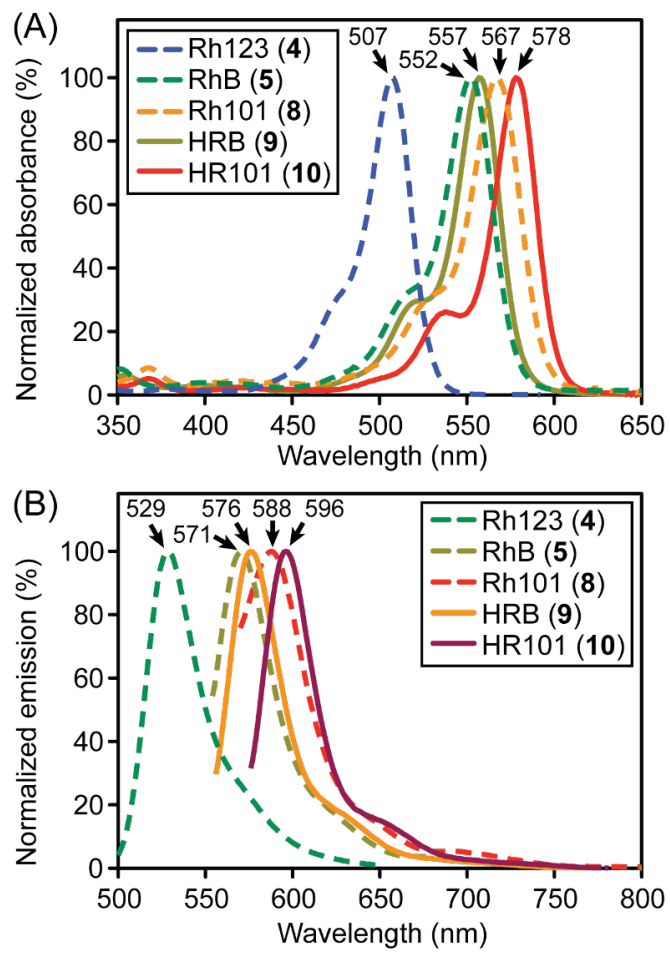

Figure 2: Normalized absorbance (Panel A) and fluorescence emission (Panel B) spectra. Fluorophores were analyzed at $10 \mu \mathrm{M}$ (absorbance) or $5 \mathrm{nM}$ (fluorescence) in $\mathrm{MeOH}$. The spectra for rhodamine 123 (4) in $\mathrm{MeOH}$ were downloaded from a publically accessible database [41]. Maximum absorbance and emission wavelengths are indicated with arrows.

The red-shifted spectra of HR101 10 compared with HRB 9 can be explained by greater delocalization of the lone pairs on nitrogen due to restricted rotation about $\mathrm{C}-\mathrm{N}$ bonds conferred by the fused rings of 10. By using the method of Williams [42], the quantum yields of $\mathbf{9}$ and $\mathbf{1 0}$ were determined relative to rhodamine B (5) and rhodamine 6G (7, Figure 3, panels A and $\mathrm{B})$, and the extinction coefficients of these compounds were quantified (Figure 3, panel C). The replacement of the carboxylate of rhodamine B (5) and rhodamine $101(\mathbf{8})$ with a methyl group slightly red shifted the absorbance and emission spectra in methanol ( $5 \mathrm{~nm}$ and 8 to $9 \mathrm{~nm}$, respectively). This change also decreased the molar extinction coefficient, as compared with the reported [43] molar extinction coefficient of rhodamine B (5) of 106,000 $\mathrm{M}^{-1} \mathrm{~cm}^{-1}$ (at $545 \mathrm{~nm}$ in ethanol) with HRB (9, 83,000 $\mathrm{M}^{-1} \mathrm{~cm}^{-1}$ at $555 \mathrm{~nm}$ in methanol). Additionally, a modest reduction in quantum yield of $\sim 0.3$ for both fluorophores was observed.
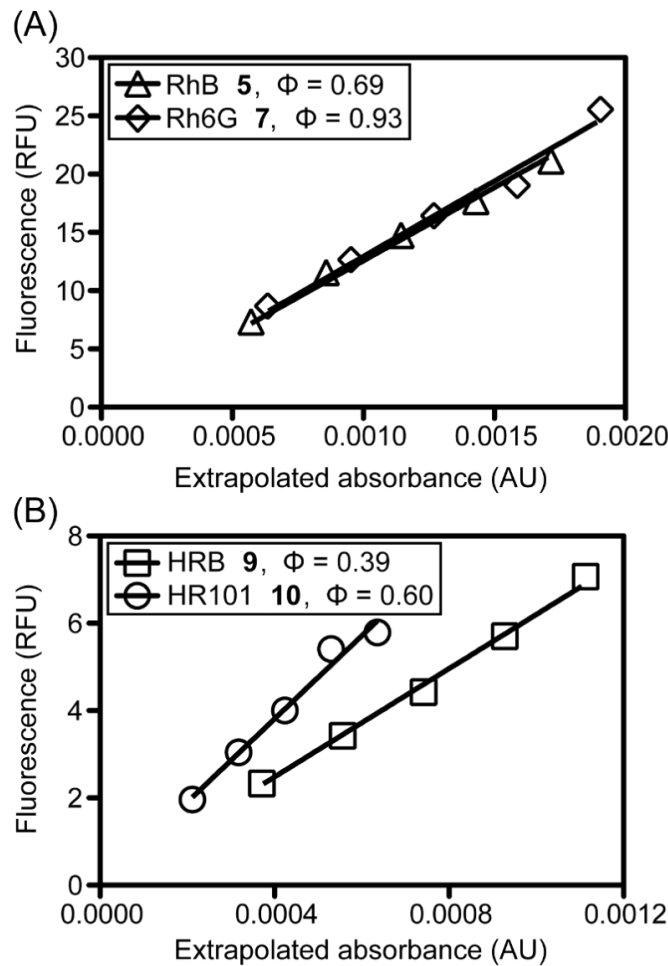

(C)

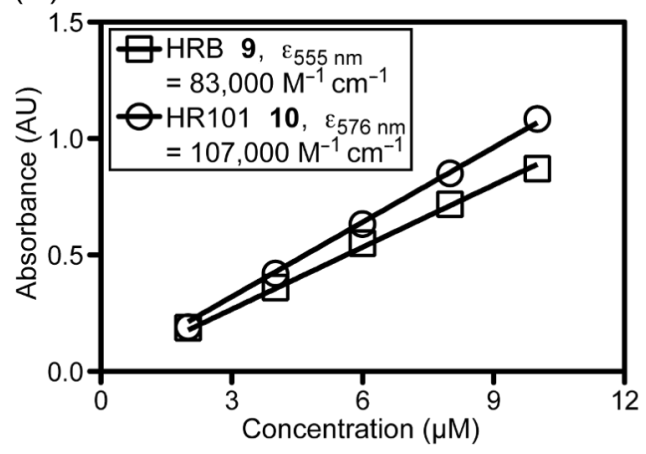

Figure 3: Linear regression used to determine spectroscopic parameters of HRB 9 and HR101 10 in MeOH. Panels A and B: Determination of quantum yields relative to rhodamine $B(5)$ [44] and rhodamine 6G (7) [45]. Panel C: Quantification of molar extinction coefficients.

Spectroscopic studies revealed that HRB $\mathbf{9}$ and HR101 $\mathbf{1 0}$ are not as bright as the carboxylate-containing parent dyes. However, because the fluorescence intensity is directly proportional to the product of the extinction coefficient and the quantum yield at excitation levels below saturation, these analogues represent very bright fluorophores for imaging applications. Potentially more important for activity in vivo, replacement of the carboxylate of rhodamine B (5) and rhodamine 101 (8) with a methyl group was predicted to substantially enhance hydrophobicity. Previously reported measurements of $\log D$ in octanol/neutral buffer solutions of rhodamine 123 (4), rhodamine B (5), and rhodamine $6 \mathrm{G}(7)$, measurements of the $\log D$ of rhodamine $101(\mathbf{8})$, HRB 9, and HR101 10 by using a 
fluorescence-based shake-flask method, and $c \cdot \log P$ values for compounds 4-10 calculated by using a recent version of CambridgeSoft ChemBioDraw software, are shown in Table 1. Although some differences exist between the calculated and measured values, the relative trends illustrate how structural modifications of these compounds are likely to affect fluorophore solubility and cellular permeability.

Table 1: Partition constants of fluorophores.

\begin{tabular}{lll} 
Fluorophore & $c \cdot \log P^{\mathrm{a}}$ & $\log D_{\text {octanol/buffer }}$ \\
\hline Rhodamine 123 (4) & 1.5 & $0.5[37],-0.6[9]$ \\
Rhodamine B (5) & -1.1 & $2.3[46]$ \\
Basic Violet 11 (6) & 3.7 & N.D. \\
Rhodamine 6G (7) & 6.5 & $2.1[37]$ \\
Rhodamine 101 (8) & 3.8 & $5.2^{\mathrm{c}}$ \\
HRB 9 & 3.4 & $5.9^{\mathrm{c}}$ \\
HR101 10 & 8.6 & $6.2^{\mathrm{c}}$ \\
\hline
\end{tabular}

${ }^{\mathrm{a} C}$ Calculated with ChemBioDraw Ultra, version 12.0.3, from structures bearing functional groups at ionization states predicted to dominate at $\mathrm{pH} 7$ (as shown in Figure 1). ${ }^{b}$ N.D. Not determined. CDetermined in octanol/buffer ${ }_{\mathrm{pH}} 7.4$ by using a fluorescence-based shake-flask method.

\section{Imaging of fluorophores in vivo by confocal microscopy}

To visualize the absorption and distribution of synthetic rhodamines and analogues in vivo, living adult $C$. elegans were initially subjected to an acute treatment followed by confocal laser scanning microscopy of mechanically immobilized whole animals $(20 \times$ objective). In contrast to previous reports where treatment with rhodamines for 36-48 $\mathrm{h}$ was required $[24,26]$, treatment with HRB 9 and HR101 10 yielded observable fluorescence in some animals within $30 \mathrm{~min}$, with most animals becoming fluorescent within $2 \mathrm{~h}$. In the assay shown in Figure 4, adult animals were treated with rhodamine 123 (4), rhodamine B (5), basic violet 11 (6), rhodamine 6G (7), rhodamine 101 (8), HRB (9), and HR101 (10) at identical fixed concentrations of $100 \mathrm{pM}$ or $1 \mathrm{nM}$ for $2 \mathrm{~h}$. Among the fluorophores examined, HRB 9, HR101 10, and basic violet 11 (6) showed the highest bioaccumulation, and the fluorescence of these three compounds could be detected at much lower concentrations than the more polar rhodamine 123 (4), rhodamine B (5), rhodamine 6G (7), and rhodamine 101 (8) fluorophores. Although basic violet 11 (6) was relatively potent, this compound appeared to be of low selectivity, staining multiple intracellular structures including membranes, mitochondria and nuclei, and occasionally was observed in the cytosol of cells of living animals. Unlike all of the other fluorophores tested, HRB 9 and HR101 10 engendered strong fluorescence in vivo after $2 \mathrm{~h}$ at concentrations as low as $100 \mathrm{pM}$.

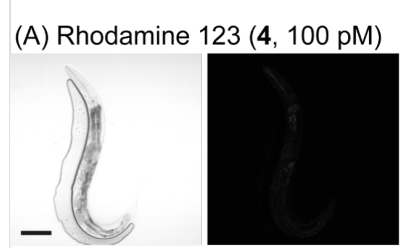

(C) Rhodamine B (5, $100 \mathrm{pM})$

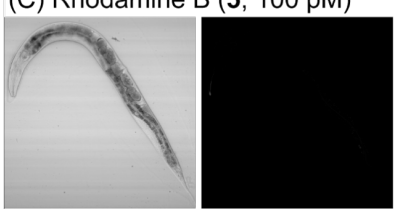

(E) Basic Violet $11(6,100$ pM)

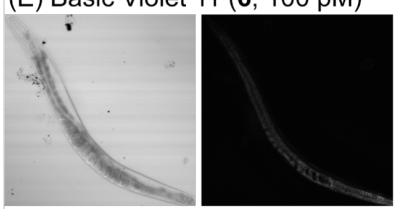

(G) Rhodamine 6G (7, $100 \mathrm{pM})$

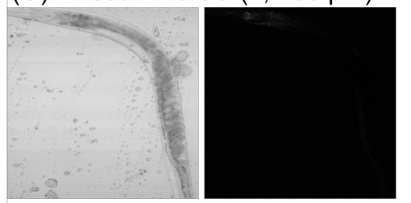

(I) Rhodamine $101(\mathbf{8}, 100 \mathrm{pM})$

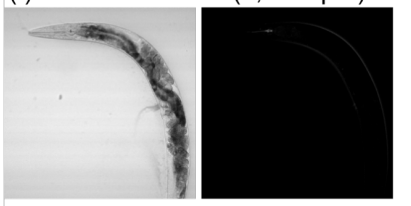

(K) $\operatorname{HRB}(\mathbf{9}, 100 \mathrm{pM})$

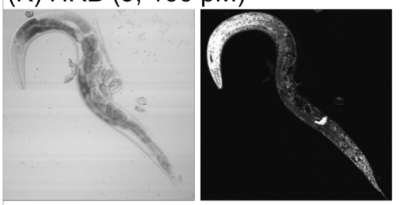

(M) HR101 (10, 100 pM)
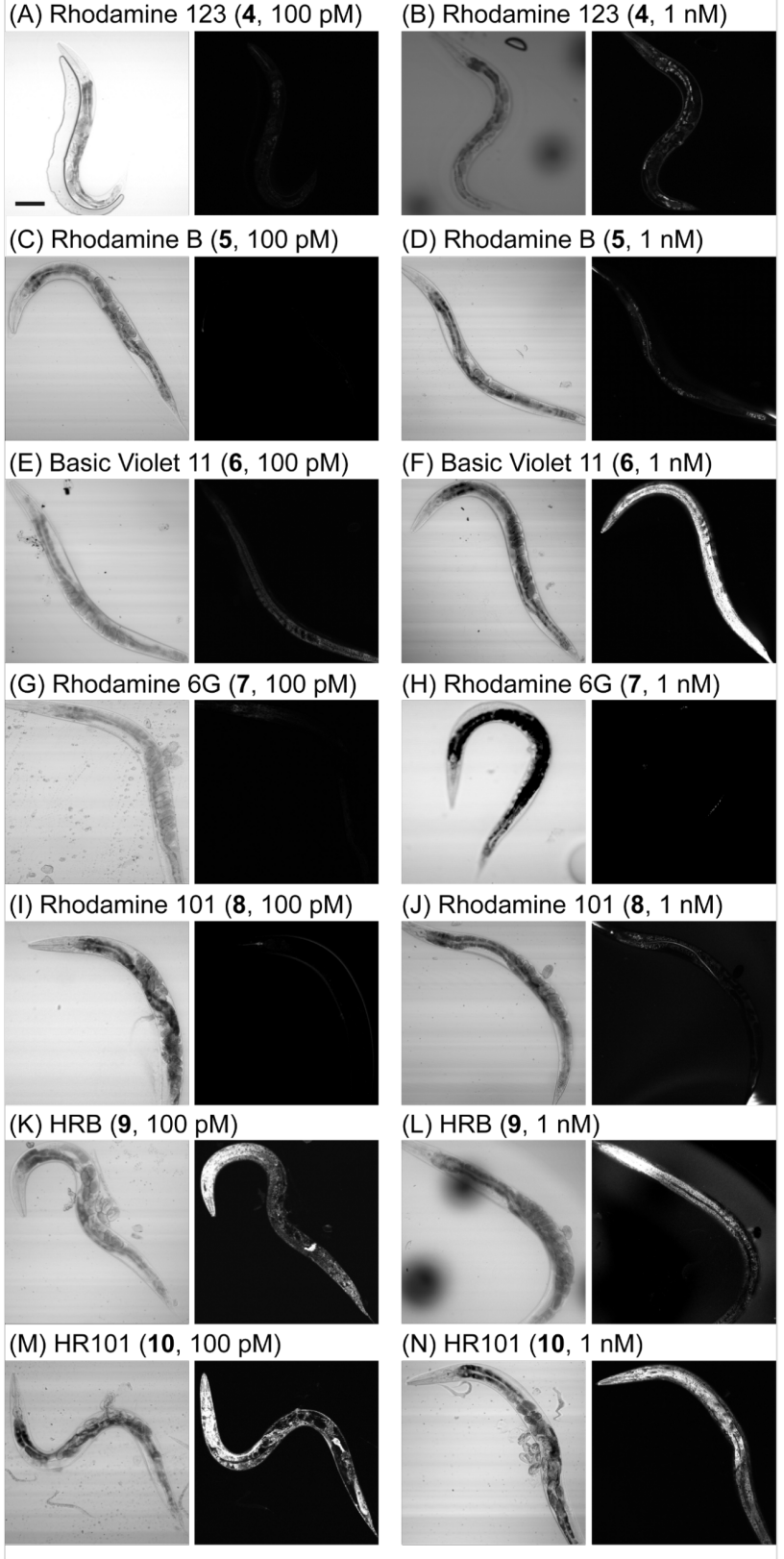

(D) Rhodamine B $(5,1 \mathrm{nM})$

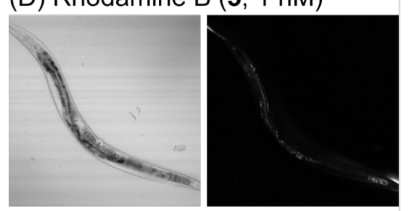

(F) Basic Violet $11(6,1 \mathrm{nM})$

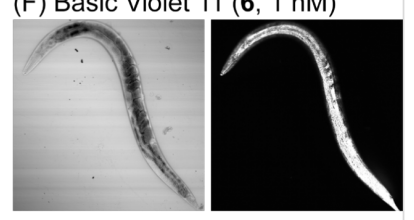

(H) Rhodamine 6G $(7,1 \mathrm{nM})$

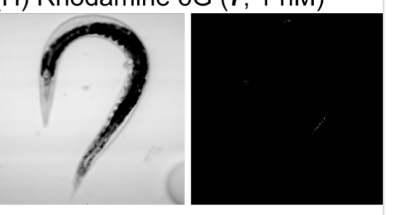

(J) Rhodamine $101(8,1 \mathrm{nM})$

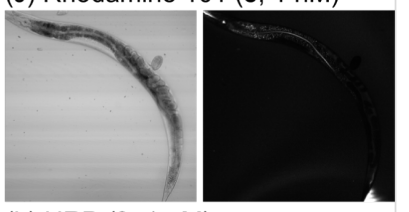

(L) $\operatorname{HRB}(9,1 \mathrm{nM})$

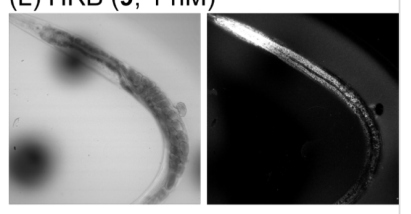

(N) HR101 (10, $1 \mathrm{nM})$

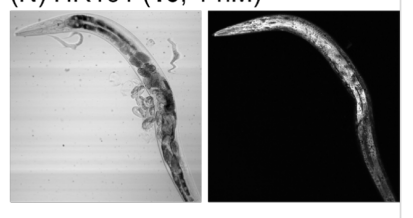

Figure 4: Differential interference contrast (DIC, left panels) and confocal laser scanning (right panels) micrographs of living $C$. elegans (20x objective) treated with synthetic compounds for $2 \mathrm{~h}$ followed by transfer to an imaging pad containing polystyrene beads for immobilization. The weak signal observed with rhodamine 123 at $1 \mathrm{nM}$ (panel B) was independently identified as autofluorescence of the intestine. Animals are oriented with the anterior end (head) to the left and the ventral side (base) down and/or toward the left. Scale bar $=100$ microns.

Higher magnification confocal microscopy $(60 \times$ objective) using a variety of fluorophore concentrations revealed that most cells of living $C$. elegans accumulate the fluorophores rhodamine 6G (7), HRB 9, and HR101 10 after treatment for $2 \mathrm{~h}$ (Figure 5). Under these conditions, the more polar rhodamine $101(\mathbf{8})$ was observed to be excluded from some 
(A) Rhodamine 6G $(7,10 \mathrm{nM})$

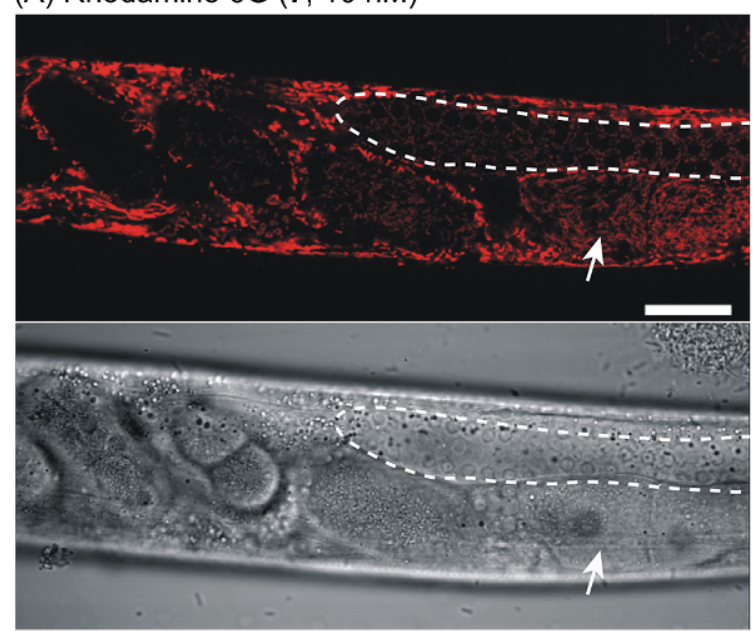

(C) HRB $(9,1 \mathrm{nM})$
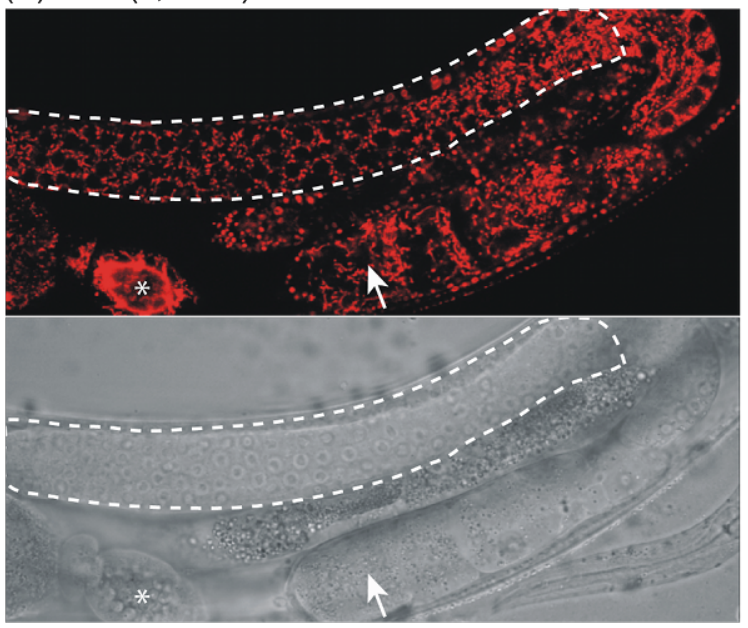

(B) Rhodamine $101(8,100 \mathrm{nM})$

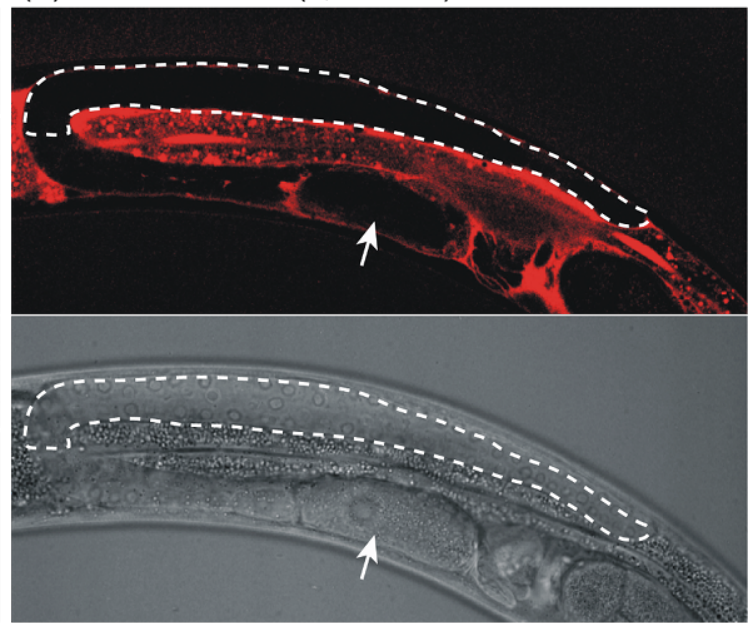

(D) HR101 (10, $1 \mathrm{nM})$

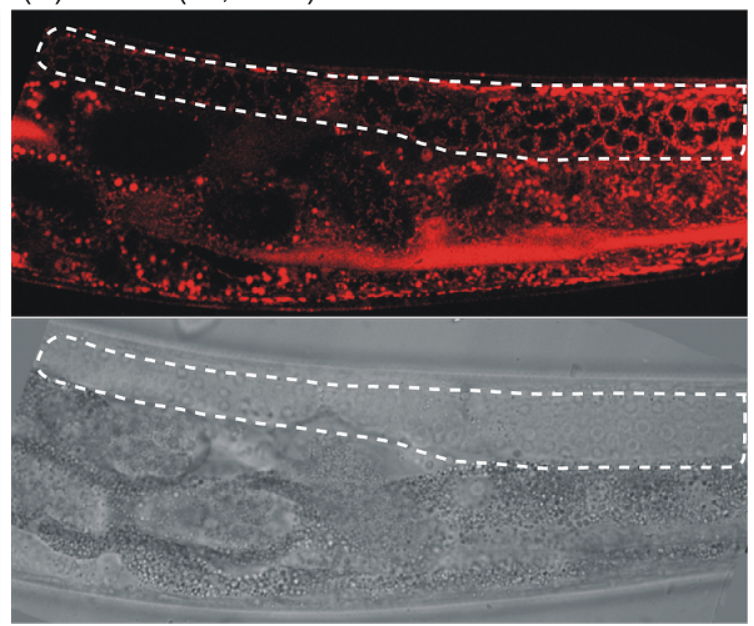

Figure 5: Panels A-D: High magnification confocal (top panels) and DIC micrographs (bottom panels, $60 \times$ objective) of young adult $C$. elegans after treatment with fluorophores for $2 \mathrm{~h}$. The distal gonad containing the germline is shown marked by white dashed lines, the anterior of the animal is to the left, and ventral is down. In Panels C, and D, strong labeling of tubular mitochondria surrounding the mitotic nuclei of the gonad can be observed as well as strong staining of mitochondria within oocytes (white arrows indicate the most proximal oocyte, where visible) and the fibrous organelle (marked with an asterisk in panel C) of spermatheca. Scale bar = 25 microns.

cells and tissues. Labeling of specific organelles by rhodamine 6G (7), HRB 9, and HR101 10 was observed in hypodermis, muscle, neurons (data not shown), and the germline of these animals (Figure 5). Examination of the pattern of staining in the germline, part of the distal gonad containing a population of germ cells that lack complete borders, demonstrated that the more specific rhodamine derivatives illuminate tubular or punctate organelles (Figure 5 and Figure 6) that are highly motile (Figure 6 and movie, Supporting Information File 1), consistent with predominant accumulation in mitochondria. These structures elongated and contracted (see movie, Supporting Information File 1) and underwent fusion and fission (Figure 6) consistent with other studies of mitochondria in C. elegans [24]. Comparative imaging indicated that rhodamine 6G (7), HRB 9, and HR101 10 represent the most specific mitochondrial stains, with similar profiles of mitochondrial labeling within the germline, but the more hydrophobic fluorophores exhibited 10 -fold higher potency. In contrast, the more polar rhodamine 101 (8), even at a 100-fold higher concentration compared with HRB 9 and HR101 10, did not penetrate into the germline under these conditions (Figure 5).

\section{Conclusion}

Genetically encoded fluorophores such as green fluorescent protein (GFP) have revolutionized cell biology and studies of physiological processes. However, fluorescent small-molecule probes continue to offer advantages for some imaging applications. One advantage illustrated here is the ability to examine 
(A) Mitochondrial fusion
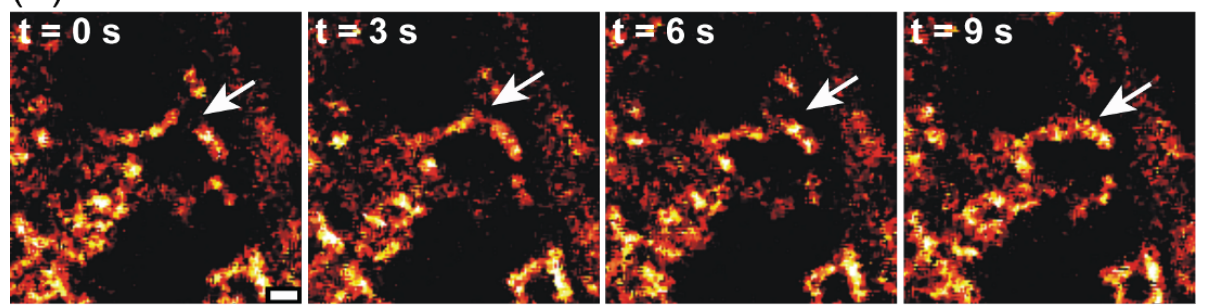

(B) Mitochondrial fission
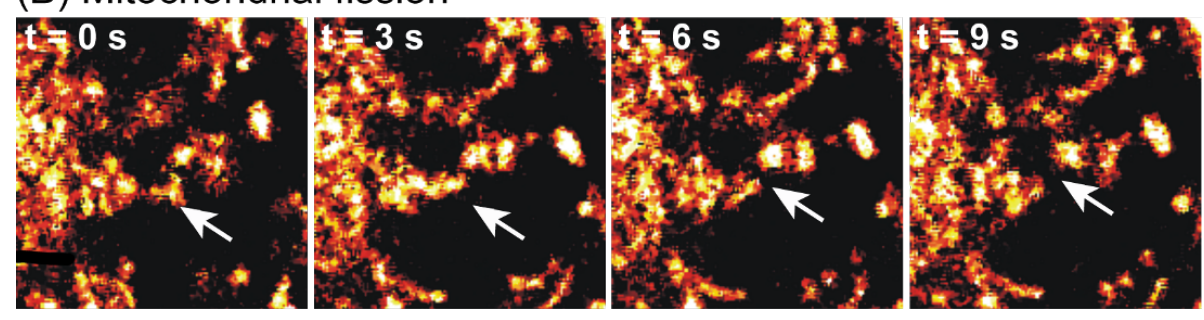

Figure 6: Images of mitochondrial motility, fusion, and fission in the germline of $C$. elegans extracted from confocal video microscopy. White arrows indicate fusion and fission of specific mitochondria. Prior to imaging, animals were treated with HRB $(9,1 \mathrm{nM}, 2 \mathrm{~h})$. Scale bar = $1 \mathrm{micron}$.

mitochondrial fusion and fission dynamics in the germline of living $C$. elegans after acute treatment with the hydrophobic rhodamine analogues HRB 9 and HR101 10. In this tissue, genetically encoded proteins are unsuitable for imaging of mitochondria, because transgenes are poorly expressed in the germline of $C$. elegans. However, genetically encoded fluorescent markers are advantageous in other contexts in that they can be more easily spatially confined to specific tissues of $C$. elegans by using cell-type specific promoters to drive gene expression. The rapid accumulation (within $2 \mathrm{~h}$ ) and high potency (effective at $\geq 100 \mathrm{pM}$ ) of HRB 9 and HR101 10 can be contrasted with previous studies [26] of rhodamine B (5) that employed treatment with $2 \mu \mathrm{M}$ for $36 \mathrm{~h}$ to image mitochondria in the germline of C. elegans. These new probes rapidly accumulate in mitochondria at low concentrations because of their more favorable pharmacokinetic properties.

Animals treated with HRB 9 and HR101 10 at $10 \mathrm{nM}$ for $2 \mathrm{~h}$ were viable and exhibited grossly wild-type movement, suggesting that mitochondrial function remains largely if not completely intact during labeling with low concentrations of these probes. In contrast, treatment with much higher concentrations of these probes (e.g., $\geq 1 \mathrm{mM}$ ) under these conditions conferred some toxicity (data not shown). By comparison, treatment of $C$. elegans with the mitochondrial poison sodium azide at $25-50 \mathrm{mM}$ rapidly causes paralysis and eventually causes death. Consequently, the high potency, low apparent toxicity, and rapid uptake of HRB 9 and HR101 10 by C. elegans has the potential to be useful in a variety of applications. For screening purposes, these compounds may be used to rapidly examine multiple genotypes of interest without the need to introduce the genetically encoded sensor to each genetic background under investigation. Alternatively, a genetically encoded fluorescent protein may be complemented with these molecular probes to perform experiments such as fluorescence recovery after photobleaching (FRAP), where one of the markers remains unbleached. Chemical probes also have a variety of half-lives in vivo, a property that may be beneficial in some assays compared to long-lived fluorescent markers, such as mitoGFP and related proteins. High-content screening of chemical libraries against $C$. elegans treated with HRB 9 and HR101 10 may facilitate the identification of inhibitors of mitochondrial fusion or fission effective in vivo, potentially enabling the discovery of new leads for the treatment of diseases associated with dysfunctional mitochondria.

A challenge associated with chemical biology studies in $C$. elegans is the low permeability of this animal to small molecules. For example, many bioactive compounds require at least a 10-fold higher dose to exhibit activity in C. elegans compared to other organisms [30], due to a number of physical and enzymatic barriers to entry of small molecules. On the exterior surface of C. elegans, the cuticular exoskeleton of these animals is a highly cross-linked carbohydrate-rich outer layer that limits access of molecules to the epidermis for potential uptake. For oral administration, molecules that are ingested by these animals must pass through an intestine replete with a wide range of xenobiotic detoxification enzymes, including 
cytochrome P450s, phase-II transferases, and efflux pumps such as P-glycoprotein [35], to reach target tissues [29]. Thus, compounds such as HRB 9 and HR101 10 that show high potency in this animal have passed through a stringent biological filter, providing a basis to justify studies in more complex and costly animal models. Fluorescence-imaging studies of small molecules in C. elegans have the potential to provide a deeper understanding of molecular modifications that facilitate the access of compounds to targets in vivo and may improve our ability to design more effective therapeutics and probes.

\section{Experimental Synthesis}

Chemical reagents were obtained from Acros, Aldrich, Alfa Aesar, or TCI America. Solvents were from EM Science. Commercial grade reagents were used without further purification unless otherwise noted. Anhydrous solvents were obtained after passage through a drying column of a solvent-purification system from GlassContour (Laguna Beach, CA). All reactions were performed under an atmosphere of dry argon or nitrogen. Reactions were monitored by analytical thin-layer chromatography on plates coated with $0.25 \mathrm{~mm}$ silica gel $60 \mathrm{~F}_{254}(\mathrm{EM}$ Science). TLC plates were visualized by UV irradiation (254 $\mathrm{nm}$ ) or stained with a solution of phosphomolybdic acid and sulfuric acid in ethanol (1:1:20). Flash column chromatography employed ICN SiliTech Silica Gel $(32-63 \mu \mathrm{m})$. Melting points were measured with a Thomas Hoover capillary melting point apparatus and are uncorrected. Infrared spectra were obtained with a Perkin Elmer 1600 Series FTIR. NMR spectra were obtained with Bruker CDPX-300, DPX-300, or DRX-400 instruments with chemical shifts reported in parts per million (ppm, $\delta$ ) referenced to either $\mathrm{CDCl}_{3}\left({ }^{1} \mathrm{H}, 7.27 \mathrm{ppm} ;{ }^{13} \mathrm{C}, 77.23\right.$ ppm), or DMSO- $d_{6}\left({ }^{1} \mathrm{H}, 2.50 \mathrm{ppm} ;{ }^{13} \mathrm{C}, 39.51 \mathrm{ppm}\right)$. High-resolution mass spectra were obtained from mass spectrometry facilities at the University of Kansas or The Pennsylvania State University (ESI and TOF). Peaks are reported as $\mathrm{m} / \mathrm{z}$. Absorbance spectra were obtained with an Agilient 8453 UV-vis spectrophotometer. Fluorescence measurements employed either a PTi MD-5020 or a Perkin-Elmer LS55 fluorescence spectrometer with a $10 \mathrm{~nm}$ excitation slit width.

5-(Diethylamino)-2-\{[4-(diethylamino)-2-hydroxyphenyl](2methylphenyl)methyl\}phenol (13): 3-Diethylaminophenol (11, $500 \mathrm{mg}, 3.0 \mathrm{mmol})$ and $o$-tolualdehyde $(\mathbf{1 2}, 175 \mu \mathrm{L}, 1.5 \mathrm{mmol})$ were dissolved in propionic acid $(15 \mathrm{~mL})$ and catalytic $p$-TsOH acid was added. The reaction was purged with argon and heated to $80-85^{\circ} \mathrm{C}$. The reaction was monitored by TLC by quenching aliquots $(100 \mu \mathrm{L})$ in aqueous saturated sodium bicarbonate $(200$ $\mu \mathrm{L}$ ), followed by extraction of the organic material with EtOAc $(200 \mu \mathrm{L})$. When all starting materials had been consumed $(5 \mathrm{~h})$, the solution was cooled to $0{ }^{\circ} \mathrm{C}$ and poured into excess aqueous sodium acetate $(3 \mathrm{M}, 100 \mathrm{~mL})$ to neutralize the propionic acid and precipitate the triarylmethane. The filtrate was collected by vacuum filtration, washed with copious amounts of water, and dried under reduced pressure to provide $13(480 \mathrm{mg}, 74 \%)$ as a tan solid. Mp $68-70{ }^{\circ} \mathrm{CM} ;{ }^{1} \mathrm{H}$ NMR (400 MHz, $\left.\mathrm{CDCl}_{3}\right) \delta 7.02$ $(\mathrm{m}, 3 \mathrm{H}), 6.90(\mathrm{~d}, J=6.8 \mathrm{~Hz}, 1 \mathrm{H}), 6.51(\mathrm{~d}, J=8.3 \mathrm{~Hz}, 1 \mathrm{H}), 6.05$ $(\mathrm{m}, 4 \mathrm{H}), 5.55(\mathrm{~s}, 1 \mathrm{H}), 3.10(\mathrm{q}, J=6.9 \mathrm{~Hz}, 8 \mathrm{H}), 2.10(\mathrm{~s}, 3 \mathrm{H})$, $0.98(\mathrm{t}, J=6.9 \mathrm{~Hz}, 12 \mathrm{H}) ;{ }^{13} \mathrm{C} \mathrm{NMR}\left(75 \mathrm{MHz}, \mathrm{CDCl}_{3}\right) \delta 154.8$, 148.1, 140.8, 136.8, 130.4, 130.4, 130.2, 115.2, 105.0, 104.8, 100.2, 100.0, 44.2, 40.8, 19.4, 12.4; IR (film) $v_{\max }: 3457,2971$, $1620,1521 \mathrm{~cm}^{-1}$; HRMS (ESI ${ }^{+}$, TOF, $\left.m / z\right):[\mathrm{M}+\mathrm{H}]^{+}$calcd for $\mathrm{C}_{28} \mathrm{H}_{36} \mathrm{O}_{2} \mathrm{~N}_{2}$, 433.2850; found, 433.2848.

6-(Diethylamino)- $\mathrm{N}, \mathrm{N}$-diethyl-9-(2-methylphenyl)-3Hxanthen-3-imine (HRB, 9): 5-(Diethylamino)-2-\{[4-(diethylamino)-2-hydroxyphenyl](2-methylphenyl)methyl phenol (13, $100 \mathrm{mg}, 0.23 \mathrm{mmol})$ and chloranil $(85 \mathrm{mg}, 0.34 \mathrm{mmol})$ were dissolved in $\mathrm{MeOH} / \mathrm{CHCl}_{3}(1: 1,10 \mathrm{~mL})$. The solution was stirred at $23{ }^{\circ} \mathrm{C}$ for $1 \mathrm{~h}$. When the reaction was complete as evidenced by TLC, the solvent was removed under reduced pressure and the residue was applied directly to a column of silica gel. Flash chromatography $\left(\mathrm{MeOH} / \mathrm{CHCl}_{3}\right.$ 1:9) afforded 9 (21 mg, 20\%) as a purple film of the chloride salt. ${ }^{1} \mathrm{H}$ NMR $\left(300 \mathrm{MHz}, \mathrm{CDCl}_{3}\right) \delta$ 7.54-7.38 (m, 3H), 7.16-7.13 (m, 3H), 6.86-6.79 (m, 4H), 3.62 (q, $J=7.2 \mathrm{~Hz}, 8 \mathrm{H}), 2.06(\mathrm{~s}, 3 \mathrm{H}), 1.33$ $(\mathrm{t}, J=7.1 \mathrm{~Hz}, 12 \mathrm{H}) ;{ }^{13} \mathrm{C} \mathrm{NMR}\left(75 \mathrm{MHz}, \mathrm{CDCl}_{3}\right) \delta 157.9$, 157.8, 155.6, 135.8, 131.6, 131.4, 130.7, 130.1, 128.7, 126.1, 114.0, 113.4, 96.5, 46.0, 19.5, 12.4; IR (film) $v_{\max }: 2981,1590$, $1179 \mathrm{~cm}^{-1}$; HRMS (ESI ${ }^{+}$, TOF, $\left.m / z\right):[\mathrm{M}]^{+}$calcd for $\mathrm{C}_{28} \mathrm{H}_{33} \mathrm{ON}_{2}$, 413.2587; found, 413.2583.

9,9'-[(2-Methylphenyl)methylene]bis(2,3,6,7-tetrahydro$1 H, 5 H$-pyrido[3,2,1-ij]quinolin-8-ol) (15): 8-Hydroxyjulolidine $(\mathbf{1 4}, 500 \mathrm{mg}, 2.6 \mathrm{mmol})$ and $o$-tolualdehyde $(\mathbf{1 2}, 154$ $\mu \mathrm{L}, 1.3 \mathrm{mmol})$ were dissolved in propionic acid $(15 \mathrm{~mL})$ and catalytic $p$-TsOH acid was added. The reaction was performed as described for the preparation of $\mathbf{1 3}$ to afford $\mathbf{1 5}$ (525 mg, $84 \%$ ) as a gray solid. Mp $170-174{ }^{\circ} \mathrm{C} ;{ }^{1} \mathrm{H}$ NMR (400 MHz, $\left.\mathrm{CDCl}_{3}\right) \delta 7.12-7.04(\mathrm{~m}, 3 \mathrm{H}), 6.73\left(\mathrm{~d}, J_{1}=7.5 \mathrm{~Hz}, 1 \mathrm{H}\right), 6.34(3$, $2 \mathrm{H}), 6.02(\mathrm{~s}, 1 \mathrm{H}), 3.35(\mathrm{~m}, 4 \mathrm{H}), 3.24(\mathrm{~m}, 4 \mathrm{H}), 2.69(\mathrm{~m}, 8 \mathrm{H})$, $2.12(\mathrm{~s}, 3 \mathrm{H}), 2.10(\mathrm{~m}, 8 \mathrm{H}) ;{ }^{13} \mathrm{C} \mathrm{NMR}\left(75 \mathrm{MHz}, \mathrm{CDCl}_{3}\right) \delta$ $150.3,139.8,136.1,132.5,129.8,127.9,127.7,125.8,125.0$, $119.6,116.6,52.1,51.5,39.9,24.8,20.1,19.7,19.1,18.5(\times 2)$; IR (film) $v_{\max }: 3270,2953,1673,1471 \mathrm{~cm}^{-1}$; HRMS $\left(\mathrm{ESI}^{+}\right.$, TOF, $m / z):[\mathrm{M}+\mathrm{H}]^{+}$calcd for $\mathrm{C}_{32} \mathrm{H}_{36} \mathrm{O}_{2} \mathrm{~N}_{2}$, 481.2850; found, 481.2875 .

16-(2-Methylphenyl)-3-oxa-9,23-diazaheptacyclo$\left[17.7 .1 .1^{\{5,9\}} \cdot 0^{\{2,17\}} \cdot 0^{\{4,15\}} \cdot 0^{\{23,27\}} .0^{\{13,28\}}\right]$ octacosa1(27),2(17),4,9(28),13,15,18-heptaen-9-ium (HR101, 10): 9,9'-[(2-Methylphenyl)methylene]bis(2,3,6,7-tetrahydro- $1 H, 5 H$ - 
pyrido[3,2,1-ij]quinolin-8-ol) $(\mathbf{1 5}, 91 \mathrm{mg}, 0.19 \mathrm{mmol})$ and chloranil $(69 \mathrm{mg}, 0.28 \mathrm{mmol})$ in $\mathrm{MeOH} / \mathrm{CHCl}_{3}(1: 1,10 \mathrm{~mL})$ were stirred at $23{ }^{\circ} \mathrm{C}$ for $1 \mathrm{~h}$. When the reaction had been complete as evidenced by TLC, the solvent was removed under reduced pressure, and the residue was applied directly to a column of silica gel. Flash chromatography $\left(\mathrm{MeOH} / \mathrm{CHCl}_{3}, 1: 9\right)$ afforded $10(27 \mathrm{mg}, 29 \%)$ as a purple film of the chloride salt. ${ }^{1} \mathrm{H} \mathrm{NMR}$ $\left(400 \mathrm{MHz}, \mathrm{CDCl}_{3}\right) \delta$ 7.44-7.25 (m, 3H), $7.07(\mathrm{~d}, J=6.9 \mathrm{~Hz}$ $1 \mathrm{H}), 6.56(\mathrm{~s}, 2 \mathrm{H}), 3.41(\mathrm{~m}, 8 \mathrm{H}), 2.97(\mathrm{t}, J=6.2 \mathrm{~Hz}, 4 \mathrm{H}), 2.58$ $(\mathrm{t}, J=5.9 \mathrm{~Hz}, 4 \mathrm{H}), 2.01(\mathrm{p}, J=6.3 \mathrm{~Hz}, 4 \mathrm{H}), 1.90(\mathrm{~s}, 3 \mathrm{H}), 1.84$ $(\mathrm{p}, J=5.3 \mathrm{~Hz}, 4 \mathrm{H}) ;{ }^{13} \mathrm{C} \mathrm{NMR}\left(75 \mathrm{MHz}, \mathrm{CDCl}_{3}\right) \delta 156.0$, 153.6, 152.6, 137.2, 133.9, 131.6, 130.2, $127.1(\times 2), 125.5$, 113.9, 106.7, 51.8, 51.4, 28.5, 21.7, 20.9, 20.8, 19.6; IR (film) $v_{\max }: 2923,1682,1596,1298 \mathrm{~cm}^{-1}$; HRMS (ESI ${ }^{+}$, TOF, $\left.m / z\right)$ : $[\mathrm{M}]^{+}$calcd for $\mathrm{C}_{32} \mathrm{H}_{33} \mathrm{ON}_{2}, 461.2587$; found, 461.2580 .

\section{Determination of $\log D$ values}

Values of $\log D$ were measured by dissolution of solids in 1:1 octanol/phosphate buffer ( $4 \mathrm{~mL}$ total volume, $5 \mathrm{mM}$ phosphate, $\mathrm{pH}$ 7.4) to provide $5 \mathrm{mM}$ solutions of the fluorophore. Samples were shaken for $24 \mathrm{~h}$ at $25{ }^{\circ} \mathrm{C}$ to equilibrate. The top and bottom $1 \mathrm{~mL}$ fractions were isolated and centrifuged at 15,000 rpm (no precipitate was observed for any of the samples). Aliquots of these fractions were diluted in octanol (derived from the top fraction) or buffer (derived bottom fraction) to generate stock solutions $(10 \times)$ appropriate for analysis. These stock solutions were further diluted 10 -fold and analyzed in a solvent mixture comprising ethanol (80\%), octanol (10\%), and phosphate buffer (10\%, pH 7.4). The ratio of fluorescence emission at $\lambda_{\max }$ was used to calculate $\log D$.

\section{Biological evaluation}

The N2 strain of C. elegans was cultured as described [47] and maintained at $20-22.5^{\circ} \mathrm{C}$. Fluorophores were added to normal growth media (NMG) liquid (at $45-55^{\circ} \mathrm{C}$ ), poured into Petri dishes $(60 \mathrm{~mm})$, and allowed to cool until solidified. Fluorophores, were prepared fresh as DMSO stocks $(1000 \times)$ from dry powders and used immediately. The final amount of DMSO exposed to animals did not exceed $0.1 \%$. Storage of fluorophores as frozen solutions in DMSO is not recommended and can result in loss of potency. Prepared media were seeded with the normal food source of OP50 E. coli and incubated overnight at room temperature to dry. Adult C. elegans animals (10-20) were added to the media and allowed to feed freely for $2 \mathrm{~h}$ prior to imaging. Animals were transferred and imaged on $10 \%$ agarose pads in the presence of $2.5 \%(\mathrm{w} / \mathrm{v})$ polystyrene beads (50 nm, Bangs Laboratory) to prevent movement. Imaging employed an Olympus FV1000 laser scanning confocal microscope and Fluoview software. Images were acquired with Planapochromat objectives.

\section{Supporting Information}

\section{Supporting Information File 1}

Supplementary time-lapse confocal microscopy video showing dynamics of mitochondrial fusion and fission in a living adult $C$. elegans animal imaged after treatment with $\operatorname{HRB}(\mathbf{9}, 1 \mathrm{nM})$ for $2 \mathrm{~h}$ followed by immobilization on an agarose pad containing polystyrene beads. Frames were acquired every 3.3 seconds, and are animated at 3 frames per second. The animal in the video is oriented such that the ventral side is left and the anterior is toward the top of the frame. The distal (mitotic) gonad arm is on the right half of the animal, whereas the proximal oocytes are on the left. Dynamic motility of mitochondria in the gonad including elongation, collapse, fusion, and fission can be observed.

[http://www.beilstein-journals.org/bjoc/content/ supplementary/1860-5397-8-243-S1.mov]

\section{Acknowledgements}

We thank the NIH (R01-CA83831, RC1-GM091086, and P20GM103638) for financial support. S.F. thanks the NIH for an IRACDA postdoctoral fellowship.

\section{References}

1. Lavis, L. D.; Raines, R. T. ACS Chem. Biol. 2008, 3, 142-155. doi:10.1021/cb700248m

2. Urano, Y.; Kamiya, M.; Kanda, K.; Ueno, T.; Hirose, K.; Nagano, T. J. Am. Chem. Soc. 2005, 127, 4888-4894. doi:10.1021/ja043919h

3. Mottram, L. F.; Boonyarattanakalin, S.; Kovel, R. E.; Peterson, B. R. Org. Lett. 2006, 8, 581-584. doi:10.1021/ol052655g

4. Mottram, L. F.; Maddox, E.; Schwab, M.; Beaufils, F.; Peterson, B. R. Org. Lett. 2007, 9, 3741-3744. doi:10.1021/ol7015093

5. Koide, K.; Song, F.; de Groh, E. D.; Garner, A. L.; Mitchell, V. D.; Davidson, L. A.; Hukriede, N. A. ChemBioChem 2008, 9, 214-218. doi:10.1002/cbic.200700565

6. Nicholls, D. G. Eur. J. Biochem. 1974, 50, 305-315. doi:10.1111/j.1432-1033.1974.tb03899.x

7. Chen, L. B. Annu. Rev. Cell Biol. 1988, 4, 155-181. doi:10.1146/annurev.cb.04.110188.001103

8. Perry, S. W.; Norman, J. P.; Barbieri, J.; Brown, E. B.; Gelbard, H. A. BioTechniques 2011, 50, 98-115. doi:10.2144/000113610

9. Belostotsky, I.; da Silva, S. M.; Paez, M. G.; Indig, G. L. Biotech. Histochem. 2011, 86, 302-314. doi:10.3109/10520295.2010.483656

10. Wu, L.; Burgess, K. J. Org. Chem. 2008, 73, 8711-8718. doi:10.1021/jo800902j

11. Modica-Napolitano, J. S.; Aprille, J. R. Adv. Drug Delivery Rev. 2001, 49, 63-70. doi:10.1016/S0169-409X(01)00125-9

12. Lim, S. H.; Wu, L.; Burgess, K.; Lee, H. B. Anti-Cancer Drugs 2009, 20, 461-468. doi:10.1097/CAD.0b013e32832b7bee

13. Smith, R. A. J.; Hartley, R. C.; Murphy, M. P. Antioxid. Redox Signaling 2011, 15, 3021-3038. doi:10.1089/ars.2011.3969 
14. Lemasters, J. J.; Ramshesh, V. K. Methods Cell Biol. 2007, 80 283-295. doi:10.1016/S0091-679X(06)80014-2

15. Huang, H.; Frohman, M. A. Methods Cell Biol. 2012, 108, 131-145. doi:10.1016/B978-0-12-386487-1.00007-9

16. Liu, X. G.; Weaver, D.; Shirihai, O.; Hajnoczky, G. EMBO J. 2009, 28 , 3074-3089. doi:10.1038/emboj.2009.255

17. Chan, D. C. Annu. Rev. Cell Dev. Biol. 2006, 22, 79-99. doi:10.1146/annurev.cellbio.22.010305.104638

18. Wang, D.; Wang, J.; Bonamy, G. M. C.; Meeusen, S.; Brusch, R. G.; Turk, C.; Yang, P.; Schultz, P. G. Angew. Chem., Int. Ed. 2012, 51, 9302-9305. doi:10.1002/anie.201204589

19. Chan, D. C. Cell 2006, 125, 1241-1252. doi:10.1016/j.cell.2006.06.010

20. Corrado, M.; Scorrano, L.; Campello, S. Int. J. Cell Biol. 2012, 2012, 729290. doi:10.1155/2012/729290

21. Sweatman, T. W.; Seshadri, R.; Israel, M. Cancer Chemother. Pharmacol. 1990, 27, 205-210. doi:10.1007/BF00685714

22. Elliott, G. S.; Mason, R. W.; Edwards, I. R. J. J. Toxicol., Clin. Toxicol. 1990, 28, 45-59. doi:10.3109/15563659008993475

23. Cygalova, L. H.; Hofman, J.; Ceckova, M.; Staud, F. J. Pharmacol. Exp. Ther. 2009, 331, 1118-1125. doi:10.1124/jpet.109.160564

24. Labrousse, A. M.; Zappaterra, M. D.; Rube, D. A.; van der Bliek, A. M. Mol. Cell 1999, 4, 815-826. doi:10.1016/S1097-2765(00)80391-3

25. Kanazawa, T.; Zappaterra, M. D.; Hasegawa, A.; Wright, A. P.; Newman-Smith, E. D.; Buttle, K. F.; McDonald, K.; Mannella, C. A.; van der Bliek, A. M. PLoS Genet. 2008, 4, e1000022. doi:10.1371/journal.pgen.1000022

26. Deng, X.; Yin, X.; Allan, R.; Lu, D. D.; Maurer, C. W.; Haimovitz-Friedman, A.; Fuks, Z.; Shaham, S.; Kolesnick, R. Science 2008, 322, 110-115. doi:10.1126/science.1158111

27. Jagasia, R.; Grote, P.; Westermann, B.; Conradt, B. Nature 2005, 433, 754-760. doi:10.1038/nature03316

28. Lu, Y.; Rolland, S. G.; Conradt, B. Proc. Natl. Acad. Sci. U. S. A. 2011, 108, E813-E822. doi:10.1073/pnas.1103218108

29. Lindblom, T. H.; Dodd, A. K. J. Exp. Zool., Part A 2006, 305, 720-730. doi:10.1002/jez.a.324

30. Burns, A. R.; Wallace, I. M.; Wildenhain, J.; Tyers, M.; Giaever, G.; Bader, G. D.; Nislow, C.; Cutler, S. R.; Roy, P. J. Nat. Chem. Biol. 2010, 6, 549-557. doi:10.1038/nchembio.380

31. Kashima, N.; Fujikura, Y.; Komura, T.; Fujiwara, S.; Sakamoto, M.; Terao, K.; Nishikawa, Y. Biogerontology 2012, 13, 337-344. doi:10.1007/s10522-012-9378-3

32. Kokel, D.; Li, Y.; Qin, J.; Xue, D. Nat. Chem. Biol. 2006, 2, 338-345. doi:10.1038/nchembio791

33. Grünz, G.; Haas, K.; Soukup, S.; Klingenspor, M.; Kulling, S. E.; Daniel, H.; Spanier, B. Mech. Ageing Dev. 2012, 133, 1-10. doi:10.1016/j.mad.2011.11.005

34. Surco-Laos, F.; Cabello, J.; Gómez-Orte, E.; González-Manzano, S.; González-Paramás, A. M.; Santos-Buelga, C.; Dueñas, M. Food Funct. 2011, 2, 445-456. doi:10.1039/c1fo10049a

35. Broeks, A.; Janssen, H. W.; Calafat, J.; Plasterk, R. H. EMBO J. 1995, 14, 1858-1866.

36. Kwok, T. C. Y.; Ricker, N.; Fraser, R.; Chan, A. W.; Burns, A.; Stanley, E. F.; McCourt, P.; Cutler, S. R.; Roy, P. J. Nature 2006, 441, 91-95. doi:10.1038/nature04657

37. Lampidis, T. J.; Castello, C.; del Giglio, A.; Pressman, B. C.; Viallet, P.; Trevorrow, K. W.; Valet, G. K.; Tapiero, H.; Savaraj, N.

Biochem. Pharmacol. 1989, 38, 4267-4271. doi:10.1016/0006-2952(89)90525-X
38. Satoh, T.; Hosokawa, M. Annu. Rev. Pharmacol. Toxicol. 1998, 38 257-288. doi:10.1146/annurev.pharmtox.38.1.257

39. Martin, V. V.; Rothe, A.; Gee, K. R. Bioorg. Med. Chem. Lett. 2005, 15, 1851-1855. doi:10.1016/j.bmcl.2005.02.017

40. Kauffman, J. M.; Imbesi, S. J.; Aziz, M. A. Org. Prep. Proced. Int. 2001, 33, 603-613. doi:10.1080/00304940109356622

41. Fluorophores.org, Database of Fluorescent Dyes and Applications. http://www.fluorophores.tugraz.at (accessed Nov 19, 2012).

42. Williams, A. T. R.; Winfield, S. A.; Miller, J. N. Analyst 1983, 108, 1067-1071. doi:10.1039/an9830801067

43. Dixon, J. M.; Taniguchi, M.; Lindsey, J. S. Photochem. Photobiol. 2005, 81, 212-213. doi:10.1562/2004-11-06-TSN-361.1

44. Velapoldi, R. A.; Tonnesen, H. H. J. Fluoresc. 2004, 14, 465-472. doi:10.1023/B:JOFL.0000031828.96368.c1

45. Magde, D.; Wong, R.; Seybold, P. G. Photochem. Photobiol. 2002, 75, 327-334. doi:10.1562/0031-8655(2002)075<0327:FQYATR>2.0.CO;2

46. Toropainen, E.; Ranta, V. P.; Talvitie, A.; Suhonen, P.; Urtti, A. Invest. Ophthalmol. Visual Sci. 2001, 42, 2942-2948.

47. Brenner, S. Genetics 1974, 77, 71-94.

\section{License and Terms}

This is an Open Access article under the terms of the Creative Commons Attribution License (http://creativecommons.org/licenses/by/2.0), which permits unrestricted use, distribution, and reproduction in any medium, provided the original work is properly cited.

The license is subject to the Beilstein Journal of Organic Chemistry terms and conditions:

(http://www.beilstein-journals.org/bjoc)

The definitive version of this article is the electronic one which can be found at: doi:10.3762/bjoc. 8.243 